\title{
]jfis
}

\section{Genetic Algorithm-based Optimal Investment Scheduling for Public Rental Housing Projects in South Korea}

\author{
Jae Ho Park ${ }^{1}$, Jung Suk $\mathrm{Yu}^{2}$, and Zong Woo Geem ${ }^{3}$ \\ ${ }^{1}$ Graduate School of Urban Planning \& Real Estate Studies, Dankook University, Yongin, Korea \\ ${ }^{2}$ School of Urban Planning \& Real Estate Studies, Dankook University, Yongin, Korea \\ ${ }^{3}$ College of Information Technology, Gachon University, Seongnam, Korea
}

Received: Apr. 7, 2018

Revised : Jun. 9, 2018

Accepted: Jun. 18, 2018

Correspondence to: Zong Woo Geem (zwgeem@gmail.com)

@The Korean Institute of Intelligent Systems

cCThis is an Open Access article distributed under the terms of the Creative Commons Attribution Non-Commercial License (http://creativecommons.org/licenses/ by-nc/3.0// which permits unrestricted noncommercial use, distribution, and reproduction in any medium, provided the original work is properly cited.

\begin{abstract}
Declining birthrate is a serious problem that threatens the sustainability of Korean society. The main cause of this phenomenon is high living cost where housing cost accounts for the majority in household expenditure. South Korea has a very low supply rate in public rental housing when compared to other OECD countries. Because young people cannot afford to buy or lease a house for their new houses, some of them postpone or even give up marriage. As a countermeasure, Gyeonggi Province (surrounding area of Seoul) recently announced the supplying plan of 10,000 public rental houses by 2020. We expect this measure to alleviate the low birthrate problem and increase the demographic sustainability of the province. This study optimizes multi-annual investment scheduling for rental housing projects using genetic algorithm while satisfying the constraints such as budget, human resources, regional balance, etc. Through the optimal investment scheduling, we hope that public corporation will supply public rental houses more efficiently and more sustainably for the community.
\end{abstract}

Keywords: Public rental house, Optimal investment scheduling, Sustainable housing, Genetic algorithm

\section{Introduction}

Low birthrate is a serious problem that threatens the sustainability of Korean society. The OECD data shows the total fertility rate of Korea is 1.21 (children per woman) and it is the lowest among developed countries (United States 1.86, United Kingdom 1.81, France 1.98, Japan 1.42, Germany 1.47) in 2014 as shown in Figure 1. Assuming no migration and unchanged mortality, a total fertility rate of 2.1 ensures a stable population.

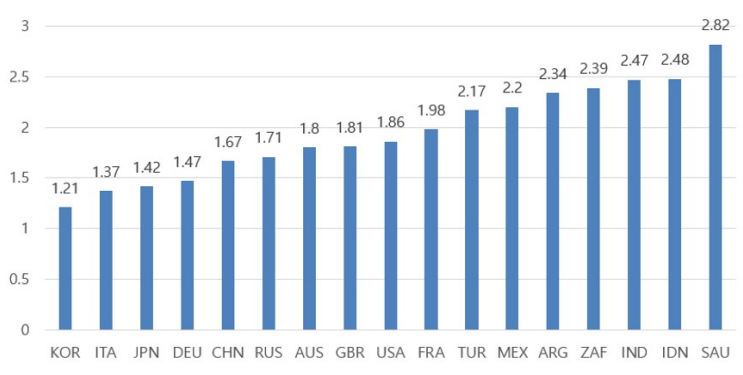

Figure 1. Fertility rates in 2014. From OECD data [1]. 


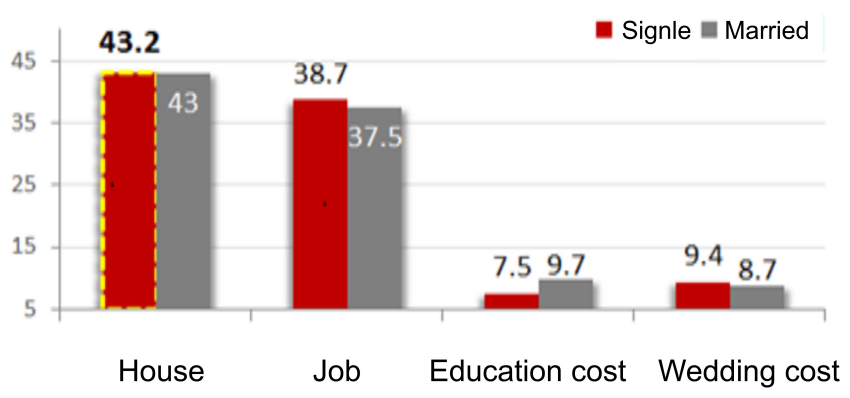

Figure 2. Desirable measures to support marriage.

Table 1. Comparison of long-term public rental house ratio in various countries

\begin{tabular}{ccccccc}
\hline Country & Korea & UK & France Japan & $\begin{array}{c}\text { OECD } \\
\text { average }\end{array}$ & $\begin{array}{c}\text { EU } \\
\text { average }\end{array}$ \\
\hline $\begin{array}{c}\text { Long-term } \\
\text { public } \\
\text { rental }\end{array}$ & $5.5 \%$ & $17 \%$ & $19 \%$ & $6.1 \%$ & $11.5 \%$ & $9.4 \%$ \\
house ratio & & & & & & \\
$\begin{array}{c}\text { Base Year } \\
\text { 2014 }\end{array}$ & 2010 & 2007 & 2008 & 2007 & 2007 \\
\hline
\end{tabular}

From Ministry of Land, Infrastructure and Transport, 2012 [5].

Two main reasons for the declining birthrate in Korea are unstable employment and high housing cost (purchasing or rental). Recent studies by Oh and Choi [2] and Kim and Hwang [3] have shown that higher housing cost is an important factor for fertility decline and postponement of having children. According to Oh and Choi [1], young people are more influenced by rental cost rather than house-purchasing price. Thus, it is important to supply public rental houses for newlyweds. The survey in 2015 by Korean Ministry of Health and Welfare shows that the housing is the number one factor related to marriage, as seen in Figure 2.

Price to income ratio (PIR) in house has been widely used, both as an indicator of house price level and as that of affordability to acquire residential property, in different geographical areas or time periods. According to Lee et al. [4], PIR in Korea (4.4) is higher than that in the United States (3.5) and Canada (3.4), but lower than those in United Kingdom (5.2), Australia (6.1) and Hong Kong (11.4). Moreover, Korea's long-term public rental housing ratio is considerably lower than that of major developed countries as observed in Table 1.

Since there are differences in conditions and social environments, it may not be adequate to simply compare the percentage of long-term public rental housing ratio. However, it is an undeniable fact that long-term public rental houses are very deficient
Table 2. Comparison between current rental house and DBH

\begin{tabular}{cccc}
\hline & Current two-room house & DBH \\
\hline $\begin{array}{c}\text { Area, } \\
\text { exclusive } \\
\left(\mathrm{m}^{2}\right)\end{array}$ & 36 & 44 \\
\hline $\begin{array}{c}\text { Floor } \\
\text { plan }\end{array}$ & Bedroom1 & & \\
\hline
\end{tabular}

in South Korea.

As a countermeasure to this problem, the government of Gyeonggi Province, metropolitan area containing Seoul, announced the plan to supply 10,000 public rental houses, called Dda Bok House (DBH; here, 'Dda Bok' means warm-hearted welfare), by 2020 on May 17, 2016.

DBH is a unique housing program that combines public rental housing and rental subsidy policies to significantly lower the burden of housing cost. In this program, the rental subsidy is proportional to the number of the babies. While the area of typical public rental house (two-room type) supplied to the newlyweds couple is $36 \mathrm{~m}^{2}$, the area of DBH is $44 \mathrm{~m}^{2}$, which is $22 \%$ wider than the current two-room type residence. Table 2 shows the comparison in details.

DBH plans to provide a safe nursing environment as well as autonomous community by creating various community-based programs. Thus, talent donators, who can give childcare, medical service, cooking, arts activity, physical activity, and local community movement, have a priority to live in the community.

The purpose of this study is to find the optimal investment scheduling for the multi-annual DBH project by maximizing the utility while meeting all the constraints.

So far, many researchers have performed useful research in the field of land-project optimization. Fei Xie et al. [6] introduced a multistage chance-constrained stochastic model for strategic planning of battery electric vehicle (BEV) inter-city fast charging infrastructure. The model was applied to a case study in California and solved by genetic algorithm. Liu et al. [7] performed land-use spatial optimization by coordinating the competitions between different land-use types in the example of Gaoqiao Town, Zhejiang Province, China. Li and Parrott [8], Haque and Asami [9], Taromi et al. [10] and Zhang and Huang [11] reached a consensus that evolutionary algorithm-based 
model is powerful tool in optimizing land use allocation in the cases of the Delaware, USA and Shenzhen, China, etc.

Other researchers have mainly been interested in private housing demand forecasting [12] and real estate appraisal forecasting with ridge regression [13]. Overall, these studies highlighted the suitability of evolutionary algorithm in the research regarding the land planning and housing demand forecasting. Unlike these studies, Park et al. [14] proposed an optimization model for deriving the optimal investment combination from the various real estate development projects. With these tools, public corporation could have reasonable investment portfolio that maximize the return of investment while meeting the multiple constraints.

In this study, an optimization model is further developed and applied to optimal investment scheduling for public rental housing projects with different groundbreaking years in South Korea.

\section{Problem Description}

Gyeonggi Urban Innovation Corporation (GICO), the subsidiary of Gyeonggi Province, is in charge of providing DBH effectively with the above-mentioned missions while considering the constraints such as human resources, annual budget, regional balance, etc., as follows:

1) Because $\mathrm{DBH}$ should be supplied in many regions simultaneously, GICO needs a lot of supervisors for construction and personnel for getting permission from local municipality. However, if GICO hires many employees at initial stage, it is a heavy burden to maintain those people after DBH project is finished. Therefore, it is desirable to maintain the proper number of personnel.

2) In order to maintain the financial soundness, GICO should make annually balanced investment rather than initial excessive investment as the DBH project is non-for-profit business.

3) In order to maintain regional balance, Gyeonggi Province is divided into 5 sub-regions such as Seoul-Busan (SB) area in orange color, West coastal (WC) area in sky-blue color, Seoul-Sinuiju (SS) area in blue color, Seoul-Wonsan (SW) area in grey color, and Eastern (ET) area in green color, as shown in Figure 3. Any sub-region cannot be excessively developed.

4) DBHs are built for newlywed, college students, junior employees and senior citizens. Thus, it is important to fairly

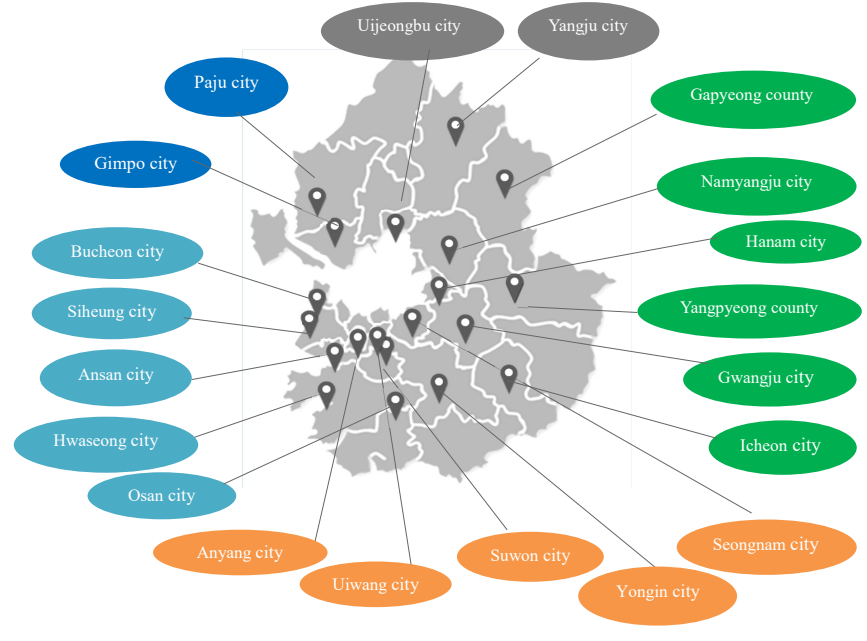

Figure 3. Major locations of DBH project in Gyeonggi Province.

supply with respect to class balance.

\section{Genetic Algorithm}

Genetic algorithm (GA) was first proposed by John Holland in the 1960s and was further developed by himself and his students and colleagues at the University of Michigan in the 1960s and the 1970s. Holland's 1975 book "Adaptation in Natural and Artificial Systems" presented the GA as an abstraction of biological evolution and gave a theoretical framework for adaptation under the GA. GA is a method for moving from one population of "chromosomes" (e.g., strings of ones and zeros, or "bits") to a new population by using a kind of "natural selection" together with the genetics-inspired operators of crossover, mutation, and inversion. Each chromosome consists of "genes" (e.g., bits), each gene being an instance of a particular "allele" (e.g., 0 or 1). The selection operator chooses those chromosomes in the population that will be allowed to reproduce, and on average the fitter chromosomes produce more offspring than the less fit ones. Crossover exchanges subparts of two chromosomes, roughly mimicking biological recombination between two single-chromosome ("haploid") organisms; mutation randomly changes the allele values of some locations in the chromosome; and inversion reverses the order of a contiguous section of the chromosome, thus rearranging the order in which genes are arrayed.

Given a clearly defined problem to be solved and a bit string representation for candidate solutions, a simple GA works as follows:

1) Start with a randomly generated population of $n l$-bit chro- 
Table 3. Samples of DBH projects

\begin{tabular}{ccccccc}
\hline Project & Project district & $\begin{array}{c}\text { Total project cost } \\
(1 \mathrm{st}, \text { 2nd, 3rd year) } \\
(\text { KRW 100 million) }\end{array}$ & $\begin{array}{c}\text { Number of } \\
\text { houses (H) }\end{array}$ & Resident type (R) & $\begin{array}{c}\text { Appraised value } \\
\text { of land (P) } \\
\left(\mathrm{KRW} / \mathrm{m}^{2}\right)\end{array}$ & Region (A) \\
\hline A & Gapyeong-eup & $190(73+117+0)$ & 48 & Junior employee & 368,600 & ET \\
B & Namyangju-Changhyeon & $61(26+35+0)$ & 48 & Newlywed & 860,500 & ET \\
C & Seongnam-Pangyo & $390(200+190+0)$ & 300 & Junior employee & $2,897,000$ & SB \\
\hline D & Suwon-Mangpo & $113(38+75+0)$ & 100 & Junior employee & 827,000 & SB \\
E & Suwon-Seodun & $130(60+70+0)$ & 100 & Junior employee & 830,100 & SB \\
\hline F & Siheung-Sincheon & $85(40+45+0)$ & 65 & Industrial worker & 409,200 & WC \\
\hline G & Siheung-Jeongwang & $380(120+200+60)$ & 290 & Newlywed/Industrial worker & 399,300 & WC \\
\hline H & Yangpyeong-Gongheung & $51(26+25+0)$ & 49 & Junior employee & 610,800 & ET \\
\hline I & Osan-Gajang & $65(15+40+10)$ & 50 & Industrial worker & 733,400 & WC \\
\hline J & Yongin-Jukjeon & $182(45+100+37)$ & 150 & Junior employee & $1,346,000$ & SB \\
\hline
\end{tabular}

mosomes (candidate solutions to a problem).

2) Calculate the fitness $f(x)$ of each chromosome $x$ in the population.

3) Repeat the following steps until $n$ offspring have been created:

a. Select a pair of parent chromosomes from the current population, the probability of selection being an increasing function of fitness. Selection is done "with replacement," meaning that the same chromosome can be selected more than once to become a parent.

b. With probability $P_{c}$ (the "crossover probability" or "crossover rate"), crossover the pair at a randomly chosen point (chosen with uniform probability) to form two offspring. If no crossover takes place, form two offspring that are exactly copies of their respective parents.

c. Mutate the two offspring at each locus with probability $P_{m}$ (the "mutation probability or "mutation rate"), and place the resulting chromosomes in the new population. If $n$ is odd, one new population member can be discarded at random.

4) Replace the current population with the new population.

5) Go to step 2).

For this study, GA utilized parameter values: population size is 100 , and mutation rate is 0.075 .

For GA computation, we used Solver software from Frontline Systems, Inc. Average computational time ranges from 15 to
20 seconds per each run and termination condition is when convergence rate is equal to or less than 0.0001 .

\section{Optimization Formulation and Computation- al Results}

To easily understand the optimal investment scheduling, 10 sample projects were selected as depicted in Table 3. Each project has different total project cost, resident type, land value and region. We want to find the optimal investment schedule by maximizing the effect of DBH supply while satisfying various constraints.

We think that the effect or utility of DBH can be maximized when more valuable houses are supplied earlier than less valuable ones. Although the housing value is not easily quantified, we instead use the appraised value of the project land. Therefore, the objective function of this scheduling problem is $\operatorname{Max} \sum H_{i} P_{i} W\left(Y_{i}\right)$, where $H_{i}$ is the number of houses in project $i ; P_{i}$ is the appraised value of land in project $i$; and $W\left(Y_{i}\right)$ is weighting factor of groundbreaking year. To find the optimal investment schedule with the maximized objective function value, we set up weighting factor system. Because the earlier the better, if the groundbreaking year is 1, the weighting factor becomes 3 (highest value); if the groundbreaking year is 2 , the weighting factor becomes 2 (medium value); and if the groundbreaking year is 3 , the weighting factor becomes 1 (lowest value).

Figure 4 shows the structure of chromosome incorporating decision variables used in GA computation. The value of each decision variable is groundbreaking year (1st, 2 nd or 3rd year). 
Table 4. Results of optimal investment scheduling for Scenario 1

\begin{tabular}{|c|c|c|c|c|c|c|c|c|c|}
\hline \multirow{2}{*}{$\begin{array}{l}\text { Project } \\
\text { name }\end{array}$} & \multirow{2}{*}{ Resident type } & \multirow{2}{*}{$\begin{array}{l}\text { Appraised value of } \\
\text { land }\left(\mathrm{KRW} / \mathrm{m}^{2}\right)\end{array}$} & \multirow{2}{*}{$\begin{array}{l}\text { Start } \\
\text { year }\end{array}$} & \multirow{2}{*}{$\begin{array}{l}\text { Weighted } \\
\text { value }\end{array}$} & \multirow{2}{*}{$\begin{array}{l}\text { Number of } \\
\text { houses }(\mathrm{H})\end{array}$} & \multicolumn{4}{|c|}{ Total project cost (KRW 100 million) } \\
\hline & & & & & & 1st year & 2nd year & 3rd year & 4th year \\
\hline $\mathrm{A}$ & Junior employee & 368,600 & 3 & 1 & 48 & - & - & 73 & 117 \\
\hline B & Newlywed & 860,500 & 1 & 3 & 48 & 26 & 35 & - & - \\
\hline $\mathrm{C}$ & Junior employee & $2,897,000$ & 1 & 3 & 300 & 200 & 190 & - & - \\
\hline $\mathrm{D}$ & Junior employee & 827,000 & 2 & 2 & 100 & - & 38 & 75 & - \\
\hline $\mathrm{E}$ & Junior employee & 830,100 & 2 & 2 & 100 & - & 60 & 70 & - \\
\hline $\mathrm{F}$ & Industrial worker & 409,200 & 3 & 1 & 65 & - & - & 40 & 45 \\
\hline G & $\begin{array}{c}\text { Newlywed/ } \\
\text { Industrial worker }\end{array}$ & 399,300 & 2 & 2 & 290 & - & 120 & 200 & 60 \\
\hline $\mathrm{H}$ & Junior employee & 610,800 & 3 & 1 & 49 & - & - & 26 & 25 \\
\hline I & Industrial worker & 733,400 & 1 & 3 & 50 & 15 & 40 & 10 & - \\
\hline $\mathrm{J}$ & Junior employee & $1,346,000$ & 1 & 3 & 150 & 45 & 100 & 37 & - \\
\hline Total & & & & & 1,200 & 286 & 583 & 531 & 247 \\
\hline
\end{tabular}

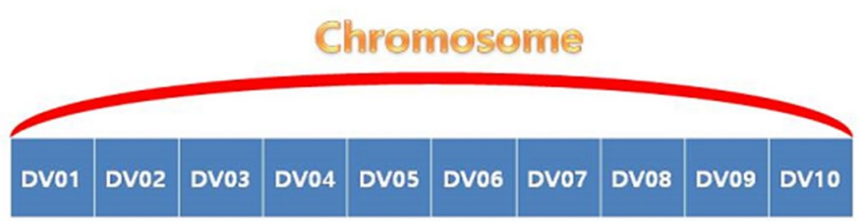

$D V \in\{1,2,3\}$

Figure 4. Structure of chromosome incorporating decision variables.

\subsection{Scenario 1}

Here, we can consider several different scenarios. In Scenario 1 , we set groundbreaking year (1st, 2 nd, or 3 rd year) of project $i$ as decision variable. If $Y_{i}$ is decision variable, it has one of three candidate values, $Y_{i} \in\{1,2,3\}$.

As previously mentioned, the objective function is Max $\sum_{i} H_{i} P_{i} W\left(Y_{i}\right)$, where $W\left(Y_{i}\right)$ is weighting factor which becomes $W\left(Y_{i}\right)=3$ if $Y_{i}=1 ; W\left(Y_{i}\right)=2$ if $Y_{i}=2$; and $W\left(Y_{i}\right)=1$ if $Y_{i}=3$.

For the human resources limitation, we limit maximum four projects to launch in year $j, N\left(Y_{i}=j\right) \leq 4, j=1,2,3$, where $N(\bullet)$ is number function which counts the total number of launched projects in year $j$.

For the project budget limitation, the maximum annual investment amount is 600 (unit $=100$ million KRW), $\sum_{i} C_{i}^{j} \leq 600$, $j=1,2,3,4$. Here, $C_{i}^{j}$ is partial investment cost occurred in year $j$ for project $i$, and 600 is about $36 \%$ of total 1,647 (100 million KRW).

For regional balance, any specific area cannot be excessively developed. In this example, among five areas (ET, SB, WC, SW, and SS), the maximum number of annually launched projects for SB area is limited up to two (the total number of SB projects in this example is four), $N\left(Y_{i}=j \& A_{i}=S B\right) \leq 2, j=1,2$, 3 . Here, $A_{i}$ is sub-region where project $i$ is included.

For resident-type balance, any specific class cannot be excessively developed. In this example, among three classes (junior employee, newlywed, and industrial worker), the maximum number of annually launched projects for junior employee is limited up to two (the total number of junior employee projects in this example is six $), N\left(Y_{i}=j \& R_{i}=\right.$ junior employee $) \leq 2$, $j=1,2,3$. Here, $R_{i}$ is resident type of project $i$.

The optimized results for this investment schedule example are shown in Table 4.

As observed in Table 4, projects B, C, I, and J will launch in 1st year; projects D, E, and G will launch in 2nd year; and projects $\mathrm{A}, \mathrm{F}$, and $\mathrm{H}$ will launch in 3rd year.

For the human resources limitation, this constraint is satisfied because the number of launched projects in 1st year is $4(\mathrm{~B}, \mathrm{C}$, $\mathrm{I}, \mathrm{J})$, that in 2 nd year is $3(\mathrm{D}, \mathrm{E}, \mathrm{G})$, and that in $3 \mathrm{rd}$ year is 3 (A, $\mathrm{F}, \mathrm{H})$.

For the project budget limitation, this constraint is satisfied because the investment amount in 1st year is 286 , that in 2 nd year is 583, that in 3rd year is 531, and that in fourth year is 247. Every of them is less than 600 .

For regional balance, this constraint is satisfied because the number of SB projects in 1st year is $2(\mathrm{C}, \mathrm{J})$, that in 2 nd year is $2(\mathrm{D}, \mathrm{E})$, and that in 3rd year is 0 . Every of them is less than 
Table 5. Results of optimal investment scheduling for Scenario 2

\begin{tabular}{|c|c|c|c|c|c|c|c|c|c|}
\hline \multirow{2}{*}{ Project } & \multirow{2}{*}{ Resident type } & \multirow{2}{*}{$\begin{array}{l}\text { Appraised value of } \\
\text { land }\left(\mathrm{KRW} / \mathrm{m}^{2}\right)\end{array}$} & \multirow{2}{*}{$\begin{array}{l}\text { Start } \\
\text { year }\end{array}$} & \multirow{2}{*}{$\begin{array}{l}\text { Weighted } \\
\text { value }\end{array}$} & \multirow{2}{*}{$\begin{array}{l}\text { Number of } \\
\text { houses }(\mathrm{H})\end{array}$} & \multicolumn{4}{|c|}{ Total project cost (KRW 100 million) } \\
\hline & & & & & & 1 st year & 2nd year & 3rd year & 4 th year \\
\hline A & Junior employee & 368,600 & 3 & 1 & 48 & - & - & 73 & 117 \\
\hline B & Newlywed & 860,500 & 1 & 3 & 48 & 26 & 35 & - & - \\
\hline $\mathrm{C}$ & Junior employee & $2,897,000$ & 1 & 3 & 300 & 200 & 190 & - & - \\
\hline $\mathrm{D}$ & Junior employee & 827,000 & 2 & 2 & 100 & - & 38 & 75 & - \\
\hline $\mathrm{E}$ & Junior employee & 830,100 & 2 & 2 & 100 & - & 60 & 70 & - \\
\hline $\mathrm{F}$ & Industrial worker & 409,200 & 3 & 1 & 65 & - & - & 40 & 45 \\
\hline G & $\begin{array}{c}\text { Newlywed/ } \\
\text { Industrial worker }\end{array}$ & 399,300 & 2 & 2 & 290 & - & 120 & 200 & 60 \\
\hline $\mathrm{H}$ & Junior employee & 610,800 & 1 & 3 & 49 & 26 & 25 & & \\
\hline I & Industrial worker & 733,400 & 2 & 2 & 50 & & 15 & 40 & 10 \\
\hline $\mathrm{J}$ & Junior employee & $1,346,000$ & 1 & 3 & 150 & 45 & 100 & 37 & - \\
\hline Total & & & & & 1,200 & 297 & 583 & 535 & 232 \\
\hline
\end{tabular}

two.

For resident-type balance, this constraint is satisfied because the number of junior employee projects in 1st year is $2(\mathrm{C}, \mathrm{J})$, that in 2 nd year is $2(\mathrm{D}, \mathrm{E})$, and that in 3 rd year is $2(\mathrm{~A}, \mathrm{H})$. Every of them is less than two.

\subsection{Scenario 2}

In Scenario 2, two constraints are loosened from Scenario 1. While the maximum number of launched projects in each year was 4 in Scenario 1, that becomes 5 in Scenario 2. And, while the maximum number of junior employee projects in each year was 2 in Scenario 1, that becomes 4 in Scenario 2. Table 5 shows the detailed results from Scenario 2.

As observed in Table 5, projects B, C, H, and J will launch in 1st year; projects D, E, G, and I will launch in 2nd year; and projects $\mathrm{A}$ and $\mathrm{F}$ will launch in 3rd year. The differences between Scenarios 1 and 2 are projects $H$ and $I$. The investment schedule of project $\mathrm{H}$ is moved forward from 3rd year to $1 \mathrm{st}$ year, and that of project I is moved back from 1st year to 2nd year for obtaining better effect of DBH project. The objective function value increased from 4,084 to 4,107 .

For the human resources limitation, this constraint is satisfied because the number of launched projects in 1 st year is $4(\mathrm{~B}, \mathrm{C}$, $\mathrm{H}, \mathrm{J})$, that in 2 nd year is $4(\mathrm{D}, \mathrm{E}, \mathrm{G}, \mathrm{I})$, and that in 3rd year is 2 $(\mathrm{A}, \mathrm{F})$. Every of them is less than 5 .

For the project budget limitation, this constraint is satisfied because the investment amount in 1st year is 297, that in 2nd year is 583, that in 3rd year is 535, and that in 4th year is 232 .
Every of them is less than 600 .

For regional balance, this constraint is satisfied because the number of SB projects in 1st year is $2(\mathrm{C}, \mathrm{J})$, that in 2 nd year is $2(\mathrm{D}, \mathrm{E})$, and that in 3rd year is 0 . Every of them is less than 2.

For resident-type balance, this constraint is satisfied because the number of junior employee projects in 1st year is $3(\mathrm{C}, \mathrm{H}$, $\mathrm{J})$, that in 2 nd year is $2(\mathrm{D}, \mathrm{E})$, and that in 3 rd year is $1(\mathrm{~A})$. Every of them is less than 4.

\subsection{Scenario 3}

In Scenario 3, the maximum annual budget is tightened from Scenario 2. We apply maximum budget of 500 (100 million KRW) instead of 600. Table 6 shows the detailed results from Scenario 3 .

As observed in Table 6, the schedules of two projects ( $G$ and I) have been changed from Scenario 2 . The investment schedule of project $\mathrm{G}$ is moved back to 3rd year from 2 nd year, and that of project I is moved forward to 1st year from 2nd year. Also, the objective function value decreased from 4,107 to 4,028.

For the human resources limitation, this constraint is satisfied because the number of launched projects in 1st year is $5(\mathrm{~B}, \mathrm{C}$, $\mathrm{H}, \mathrm{I}, \mathrm{J})$, that in 2 nd year is $2(\mathrm{D}, \mathrm{E})$, and that in $3 \mathrm{rd}$ year is $3(\mathrm{~A}$, F, G). Every of them is less than 5 .

For the project budget limitation, this constraint is satisfied because the investment amount in 1st year is 312 , that in 2 nd year is 488 , that in 3 rd year is 425 , and that in 4 th year is 362 . Every of them is less than 500 .

For regional balance, this constraint is satisfied because the 
Table 6. Results of optimal investment scheduling for Scenario 3

\begin{tabular}{|c|c|c|c|c|c|c|c|c|c|}
\hline \multirow{2}{*}{ Project } & \multirow{2}{*}{ Resident type } & \multirow{2}{*}{$\begin{array}{l}\text { Appraised value of } \\
\text { land }\left(\mathrm{KRW} / \mathrm{m}^{2}\right)\end{array}$} & \multirow{2}{*}{$\begin{array}{l}\text { Start } \\
\text { year }\end{array}$} & \multirow{2}{*}{$\begin{array}{l}\text { Weighted } \\
\text { value }\end{array}$} & \multirow{2}{*}{$\begin{array}{l}\text { Number of } \\
\text { houses }(\mathrm{H})\end{array}$} & \multicolumn{4}{|c|}{ Total project cost (KRW 100 million) } \\
\hline & & & & & & 1st year & 2nd year & 3rd year & 4th year \\
\hline $\mathrm{A}$ & Junior employee & 368,600 & 3 & 1 & 48 & - & - & 73 & 117 \\
\hline B & Newlywed & 860,500 & 1 & 3 & 48 & 26 & 35 & - & - \\
\hline $\mathrm{C}$ & Junior employee & $2,897,000$ & 1 & 3 & 300 & 200 & 190 & - & - \\
\hline $\mathrm{D}$ & Junior employee & 827,000 & 2 & 2 & 100 & - & 38 & 75 & - \\
\hline $\mathrm{E}$ & Junior employee & 830,100 & 2 & 2 & 100 & - & 60 & 70 & - \\
\hline $\mathrm{F}$ & Industrial worker & 409,200 & 3 & 1 & 65 & - & - & 40 & 45 \\
\hline G & $\begin{array}{c}\text { Newlywed/ } \\
\text { Industrial worker }\end{array}$ & 399,300 & 3 & 1 & 290 & - & & 120 & 200 \\
\hline $\mathrm{H}$ & Junior employee & 610,800 & 1 & 3 & 49 & 26 & 25 & & \\
\hline I & Industrial worker & 733,400 & 1 & 3 & 50 & 15 & 40 & 10 & \\
\hline $\mathrm{J}$ & Junior employee & $1,346,000$ & 1 & 3 & 150 & 45 & 100 & 37 & - \\
\hline Total & & & & & 1,200 & 312 & 488 & 425 & 362 \\
\hline
\end{tabular}

number of SB projects in 1st year is $2(C, J)$, that in 2 nd year is $2(\mathrm{D}, \mathrm{E})$, and that in 3rd year is 0 . Every of them is less than 2.

For resident-type balance, this constraint is satisfied because the number of junior employee projects in 1st year is $3(\mathrm{C}, \mathrm{H}$, $\mathrm{J})$, that in 2 nd year is $2(\mathrm{D}, \mathrm{E})$, and that in 3 rd year is $1(\mathrm{~A})$. Every of them is less than 4.

\subsection{Scenario 4 (Real-World Example)}

Now we consider a real-world investment schedule problem, which has 31 projects. Table 7 shows the details of the projects. Because the construction costs of some projects marked with asterisk are not determined yet, those costs are assumed by multiplying 130 million KRW and number of houses. Here, resident type consists of junior employee (JE), newlywed (NW), industrial worker (IW), senior citizen (SC), and to-be-determined (TBD).

Actually, 11 projects (A, B, D, H, J, K, L, M, N, O, and P) have already launch-ed in 2017 by GICO. Thus, the decision variables of those projects should have a value of one, which means 1 st year, and those of other 20 projects should have a value of two or three, $Y_{i} \in\{2,3\}$. Here, the number of candidate investment schedule solutions becomes $2^{20}(\geq 1,000,000)$ because 20 projects have two choices. As already utilized, the objective function is $\operatorname{Max} \sum_{i} H_{i} P_{i} W\left(Y_{i}\right)$.

For the human resources limitation, we limit maximum 11 projects to launch in year $j, N\left(Y_{i}=j\right) \leq 11, j=2,3$.

For the project budget limitation, the maximum annual investment amount is 2,000 $\left(10^{8} \mathrm{KRW}\right), \sum_{i} C_{i}^{j} \leq 2,000, j=2$,
3 , 4. Here, 2,000 is around $1 / 3$ of total project cost 6,102 .

For regional balance, the maximum number of annually launched projects for SB area is limited up to $3, N\left(Y_{i}=j\right.$ $\left.\& A_{i}=S B\right) \leq 3, j=2,3$.

For resident-type balance, the maximum number of annually launched projects for junior employee is limited up to 2 , $N\left(Y_{i}=j \& R_{i}=J E\right) \leq 2, j=2,3$.

The optimized results for this real-world investment schedule problem are shown in Table 8.

As observed in Table 8, 11 projects $(\mathrm{C}, \mathrm{F}, \mathrm{Q}, \mathrm{U}, \mathrm{V}, \mathrm{W}, \mathrm{X}, \mathrm{Z}$, AA, BB, CC) will launch in 2nd year; and 9 projects (E, G, I, $\mathrm{R}, \mathrm{S}, \mathrm{T}, \mathrm{Y}, \mathrm{DD}, \mathrm{EE}$ ) will launch in 3rd year.

For the human resources limitation, this constraint is satisfied because the number of launched projects in 1st year is 11 , and that in 2nd year is 9. Every of them is less than 11 .

For the project budget limitation, this constraint is satisfied because the investment amount in 2 nd year is 1,886 , that in $3 \mathrm{rd}$ year is 1,981 , and that in 4 th year is 1,149 . Every of them is less than 2,000 .

For regional balance, this constraint is satisfied because the number of SB projects in 2nd year is $3(\mathrm{C}, \mathrm{Q}, \mathrm{W})$, and that in 3rd year is 3 (E, R, EE). Every of them is less than 3 .

For resident-type balance, this constraint is satisfied because the number of JE projects in 2nd year is $2(\mathrm{C}, \mathrm{X})$, and that in 3rd year is $2(\mathrm{E}, \mathrm{R})$. Every of them is less than 2 . 
Table 7. Total DBH projects

\begin{tabular}{|c|c|c|c|c|c|c|}
\hline Project & Project district & $\begin{array}{c}\text { Project cost } \\
(1 \mathrm{st}, 2 \mathrm{nd}, 3 \mathrm{rd} \text { year }) \\
\left(10^{8} \mathrm{KRW}\right)\end{array}$ & $\begin{array}{l}\text { Number of } \\
\text { houses }\end{array}$ & $\begin{array}{l}\text { Resident } \\
\text { type }\end{array}$ & $\begin{array}{l}\text { Land value } \\
\left(\mathrm{KRW} / \mathrm{m}^{2}\right)\end{array}$ & Region \\
\hline A & Gapyeong-eup & $190(73+117+0)$ & 48 & JE & 368,600 & ET \\
\hline B & Namyangju-Changhyeon & $61(26+35+0)$ & 48 & NW & 860,500 & ET \\
\hline $\mathrm{C}^{*}$ & Seongnam-Pangyo & $390(200+190+0)$ & 300 & $\mathrm{JE}$ & $2,897,000$ & SB \\
\hline $\mathrm{D}$ & Suwon-Mangpo & $113(38+75+0)$ & 100 & JE & 827,000 & SB \\
\hline $\mathrm{E}$ & Suwon- Seodun & $130(60+70+0)$ & 100 & $\mathrm{JE}$ & 830,100 & SB \\
\hline $\mathrm{F}^{*}$ & Siheung- Sincheon & $85(40+45+0)$ & 65 & IW & 409,200 & WC \\
\hline $\mathrm{G}^{*}$ & Siheung-Jeongwang & $380(120+200+60)$ & 290 & NW/IW & 399,300 & WC \\
\hline $\mathrm{H}$ & Yangpyeong-Gongheung & $51(26+25+0)$ & 49 & $\mathrm{JE}$ & 610,800 & ET \\
\hline$I^{*}$ & Osan-Gajang & $65(15+40+10)$ & 50 & IW & 733,400 & WC \\
\hline $\mathrm{J}$ & Yongin-Jukjeon & $182(45+100+37)$ & 150 & JE & $1,346,000$ & SB \\
\hline K & Suwon-Gwanggyo1 & $393(252+141+0)$ & 204 & NW & $2,211,000$ & SB \\
\hline $\mathrm{L}$ & Anyang-Gwanyang 1 & $71(71+0+0)$ & 56 & NW & $2,428,000$ & SB \\
\hline M & Hwaseong-Jinan & $27(27+0+0)$ & 31 & $\mathrm{JE}$ & 674,300 & WC \\
\hline $\mathrm{N}$ & Suwon-Woncheon & $196(78+118+0)$ & 152 & $\mathrm{SC}$ & $2,145,000$ & SB \\
\hline $\mathrm{O}$ & Paju-Byungwon & $134(67+67+0)$ & 50 & $\mathrm{SC}$ & 966,000 & SS \\
\hline $\mathrm{P}$ & Uiwang-Bugok & $56(13+43+0)$ & 50 & $\mathrm{JE}$ & $1,151,000$ & SB \\
\hline $\mathrm{Q}^{*}$ & Anyang-Gwanyang2 & $390(200+190+0)$ & 300 & NW & $1,554,000$ & SB \\
\hline $\mathrm{R}^{*}$ & Yongin-Yeosung & $130(70+60+0)$ & 100 & $\mathrm{JE}$ & $1,229,000$ & SB \\
\hline $\mathrm{S}^{*}$ & Icheon-Gwango & $130(70+60+0)$ & 100 & $\mathrm{SC}$ & 819,600 & ET \\
\hline $\mathrm{T}^{*}$ & Gwangju-Yeokdong & $650(230+220+200)$ & 500 & NW & 318,500 & ET \\
\hline $\mathrm{U}^{*}$ & Ansan-Wonsi & $299(100+100+99)$ & 230 & IW & 240,000 & WC \\
\hline $\mathrm{V}^{*}$ & Hanam-Deokpung2 & $169(80+89+0)$ & 130 & TBD & $2,448,000$ & ET \\
\hline $\mathrm{W}^{*}$ & Yongin-Yeongdeok & $130(70+60+0)$ & 100 & TBD & $1,264,000$ & SB \\
\hline$X^{*}$ & Uijeongbu-Howon & $130(70+60+0)$ & 100 & JE & 777,300 & SW \\
\hline $\mathrm{Y}^{*}$ & Yangpyeong-Changdae & $91(45+46+0)$ & 70 & $\mathrm{SC}$ & 417,900 & ET \\
\hline$Z^{*}$ & Bucheon-Jungdong2 & $260(120+140+0)$ & 200 & TBD & $4,770,000$ & WC \\
\hline $\mathrm{AA}^{*}$ & Bucheon-Songnae & $130(70+60+0)$ & 100 & TBD & $1,341,000$ & WC \\
\hline $\mathrm{BB}^{*}$ & Yangpyeong-Yanggeun & $444(150+200+94)$ & 341 & NW & $1,631,000$ & ET \\
\hline $\mathrm{CC}^{*}$ & Gimpo-Sau & $65(65+0+0)$ & 50 & TBD & $1,490,000$ & SS \\
\hline DD* & Yangju-Nambang & $130(70+60+0)$ & 100 & TBD & 275,500 & SW \\
\hline $\mathrm{EE}^{*}$ & Suwon-Pajang & $430(130+200+100)$ & 330 & TBD & $1,070,000$ & SB \\
\hline
\end{tabular}

\section{Conclusions}

Public rental house is essential for low-income classes who cannot afford to purchase a house or pay a high security deposit (some property owners require $80 \%$ of house prices). South Korea has lowest fertility rate among OECD countries and the main reason is cost burden of house purchase or rent. Further- more, public rental housing ratio in South Korea is considerably lower than that of major OECD countries. Thus, it is urgent to expand the supply of public rental houses for the housing sustainability of South Korea.

This study proposed a GA-based optimization model for multi-annual investment scheduling of public rental house project, obtaining good results. This cannot be easily obtained if we use 
Table 8. Results of optimal investment scheduling for Scenario 4

\begin{tabular}{|c|c|c|c|c|c|c|c|c|}
\hline \multirow{2}{*}{ Project } & \multirow{2}{*}{$\begin{array}{l}\text { Resident } \\
\text { type }\end{array}$} & \multirow{2}{*}{$\begin{array}{l}\text { Land value } \\
\left(\mathrm{KRW} / \mathrm{m}^{2}\right)\end{array}$} & \multirow{2}{*}{$\begin{array}{l}\text { Start } \\
\text { year }\end{array}$} & \multirow{2}{*}{$\begin{array}{c}\text { Number of } \\
\text { houses }\end{array}$} & \multicolumn{4}{|c|}{ Total Project Cost $\left(10^{8} \mathrm{KRW}\right)$} \\
\hline & & & & & 1st year & 2nd year & 3rd year & 4th year \\
\hline $\mathrm{A}^{*}$ & $\mathrm{JE}$ & 368,600 & 1 & 48 & 73 & 117 & & \\
\hline $\mathrm{B}^{*}$ & $\mathrm{JE}$ & 860,500 & 1 & 48 & 26 & 35 & & \\
\hline $\mathrm{C}$ & $\mathrm{JE}$ & $2,897,000$ & 2 & 300 & & 200 & 190 & \\
\hline $\mathrm{D}^{*}$ & $\mathrm{JE}$ & 827,000 & 1 & 100 & 38 & 75 & & \\
\hline $\mathrm{E}$ & $\mathrm{JE}$ & 830,100 & 3 & 100 & & & 60 & 70 \\
\hline $\mathrm{F}$ & IW & 409,200 & 2 & 65 & & 40 & 45 & \\
\hline $\mathrm{G}$ & NW/IW & 399,300 & 3 & 290 & & & 120 & 200 \\
\hline $\mathrm{H}^{*}$ & JE & 610,800 & 1 & 49 & 26 & 25 & & \\
\hline I & IW & 733,400 & 3 & 50 & & & 15 & 40 \\
\hline $\mathrm{J}^{*}$ & $\mathrm{JE}$ & $1,346,000$ & 1 & 150 & 45 & 100 & 37 & \\
\hline $\mathrm{K}^{*}$ & NW & $2,211,000$ & 1 & 204 & 252 & 141 & & \\
\hline $\mathrm{L}^{*}$ & NW & $2,428,000$ & 1 & 56 & 71 & & & \\
\hline $\mathbf{M}^{*}$ & $\mathrm{JE}$ & 674,300 & 1 & 31 & 27 & & & \\
\hline $\mathrm{N}^{*}$ & SC & $2,145,000$ & 1 & 152 & 78 & 118 & & \\
\hline $\mathrm{O} *$ & $\mathrm{SC}$ & 966,000 & 1 & 50 & 67 & 67 & & \\
\hline $\mathrm{P}^{*}$ & $\mathrm{JE}$ & $1,151,000$ & 1 & 50 & 13 & 43 & & \\
\hline Q & NW & $1,554,000$ & 2 & 300 & & 200 & 190 & \\
\hline $\mathrm{R}$ & $\mathrm{JE}$ & $1,229,000$ & 3 & 100 & & & 70 & 60 \\
\hline$S$ & SC & 819,600 & 3 & 100 & & & 70 & 60 \\
\hline $\mathrm{T}$ & NW & 318,500 & 3 & 500 & & & 230 & 220 \\
\hline $\mathrm{U}$ & IW & 240,000 & 2 & 230 & & 100 & 100 & 99 \\
\hline $\mathrm{V}$ & TBD & $2,448,000$ & 2 & 130 & & 80 & 89 & \\
\hline $\mathrm{W}$ & TBD & $1,264,000$ & 2 & 100 & & 70 & 60 & \\
\hline$X$ & $\mathrm{JE}$ & 777,300 & 2 & 100 & & 70 & 60 & \\
\hline $\mathrm{Y}$ & SC & 417,900 & 3 & 70 & & & 45 & 46 \\
\hline $\mathrm{Z}$ & TBD & $4,770,000$ & 2 & 200 & & 120 & 140 & \\
\hline AA & TBD & $1,341,000$ & 2 & 100 & & 70 & 60 & \\
\hline $\mathrm{BB}$ & NW & $1,631,000$ & 2 & 341 & & 150 & 200 & 94 \\
\hline $\mathrm{CC}$ & TBD & $1,490,000$ & 2 & 50 & & 65 & & \\
\hline DD & TBD & 275,500 & 3 & 100 & & & 70 & 60 \\
\hline $\mathrm{EE}$ & TBD & $1,070,000$ & 3 & 330 & & & 130 & 200 \\
\hline Total & & & & 4,494 & 716 & 1,886 & 1,981 & 1,149 \\
\hline
\end{tabular}

only "engineering intuition". The optimization model becomes very useful and practical tool for the massive $\mathrm{DBH}$ project while meeting various constraints such as limited human resources, limited annual budget, regional supply balance, and residenttype balance. We hope this optimization approach will be used for the investment scheduling of similar public projects in the future.

The proposed scheduling optimization model may be further applied to various cases such as financial investment, advisory service, and facility repair, as follows:

- Financial investment: Financial investor may use the scheduling optimization model with various investment 
projects, which have different maturity, rate of return, and risk with limited financial resources to obtain multiannual desirable cash flow.

- Advisory service: Consulting firm, accounting firm, or law firm may use the scheduling optimization model with limited human resources to carry out more consulting projects simultaneously.

- Facility repair: City officials may use the scheduling optimization model for lots of infrastructure facilities such as road, water supply and sewer pipe with limited human and financial resources to maintain facilities.

\section{Conflict of Interest}

No potential conflict of Interest relevant to this article was reported.

\section{Acknowledgements}

This research was supported by the Ministry of Science and ICT, Korea, under the Information Technology Research Center support program (No. IITP-2018-2017-0-01630) supervised by the Institute for Information \& communications Technology Promotion (IITP).

\section{References}

[1] OECD, "Fertility rates," Available https://data.oecd.org/ pop/fertility-rates.htm

[2] C. S. Oh and S. H. Choi, "The empirical study on the cause of low fertility-factors to impact on falling of nuptiality and rising of age at first marriage," Journal of Public Welfare Administration, vol. 22, no. 1, pp. 91-125, 2012.

[3] M. Y. Kim and J. Y. Hwang, "Housing price and the level and timing of fertility in Korea: an empirical analysis of 16 cities and provinces," Health and Social Welfare Review, vol. 36, no. 1, pp. 118-142, 2016. https://doi.org/ 10.15709/hswr.2016.36.1.118

[4] C. M. Lee, H. A. Kim, and M. Cho, "A comparative analysis on house price to income ratios: focusing on measurement issues," Housing Studies Review, vol. 20, no. 4, pp. 5-25, 2012.
[5] Ministry of Land, Infrastructure and Transport, Housing Business Handbook. Seoul: Ministry of Land, Infrastructure and Transport, 2012.

[6] F. Xie, C. Liu, S. Li, Z. Lin, and Y. Huang, "Long-term strategic planning of inter-city fast charging infrastructure for battery electric vehicles," Transportation Research Part E: Logistics and Transportation Review, vol. 109, pp. 261-276, 2018. https://doi.org/10.1016/j.tre.2017.11.014

[7] Y. Liu, W. Tang, J. He, Y. Liu, T. Ai, and D. Liu, "A land-use spatial optimization model based on genetic optimization and game theory," Computers, Environment and Urban Systems, vol. 49, pp. 1-14, 2015. https://doi.org/10.1016/j.compenvurbsys.2014.09.002

[8] X. Li and L. Parrott, "An improved genetic algorithm for spatial optimization of multi-objective and multi-site land use allocation," Computers, Environment and Urban Systems, vol. 59, pp. 184-194, 2016. https://doi.org/10. 1016/j.compenvurbsys.2016.07.002

[9] A. Haque and Y. Asami, "Optimizing urban land use allocation for planners and real estate developers," Computers Environment and Urban Systems, vol. 46, pp. 57-69, 2014. https://doi.org/10.1016/j.compenvurbsys.2014.04.004

[10] R. Taromi, M. DuRoss, B. Chen, A. Faghri, M. Li, and T. DeLiberty, "A multiobjective land development optimization model: the case of New Castle County, Delaware," Transportation Planning and Technology, vol. 38, no. 3, pp. 277-304, 2015. https://doi.org/10.1080/03081060. 2014.997450

[11] W. Zhang and B. Huang, "Land use optimization for a rapidly urbanizing city with regard to local climate change: Shenzhen as a case study," Journal of Urban Planning and Development, vol. 141, no. 1, 2015. https://doi.org/10. 1061/(asce)up.1943-5444.0000200

[12] S. T. Ng, M. Skitmore, and K. F. Wong, "Using genetic algorithms and linear regression analysis for private housing demand forecast," Building and Environment, vol. 43, no. 6, pp. 1171-1184, 2008. https://doi.org/10.1016/j.buildenv. 2007.02.017

[13] J. J. Ahn, H. W. Byun, K. J. Oh, and T. Y. Kim, "Using ridge regression with genetic algorithm to enhance real estate appraisal forecasting," Expert Systems with 
Applications, vol. 39, no. 9, pp. 8369-8379, 2012.https: //doi.org/10.1016/j.eswa.2012.01.183

[14] J. H. Park, Z. W. Geem, and J. S. Yu, "The optimal investment portfolio for land development projects of public company," Korean Real Estate Review, vol. 26, no. 3, pp. 23-38, 2016.

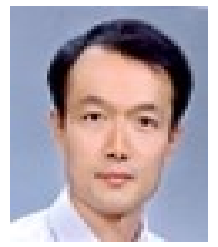

Jae Ho Park received his B.A. in economics from Yonsei University in 1997, M.A. in Graduate School of Real Estate \& Construction from Dankook University in 2013, and currently pursuing Ph.D. in Graduate School of Urban Planning \& Real Estate Studies at Dankook University. He passed the Uniform Certified Public Accountant Examination in California, U.S.A. in 2003. Now he works as a general manager at Gyeonggi Urban Innovation Corporation which develops new cities, housing lands, industrial complexes and constructs housing units to the vulnerable in Gyeonggi province, South Korea.

E-mail : jhpark1@ gico.or.kr

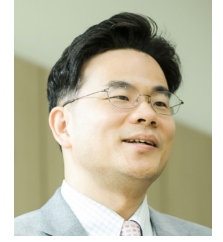

Jung-Suk Yu is an associate professor in School of Urban Planning \& Real Estate Studies at Dankook University. He teaches and researches in the field of real estate finance $\&$ investments. He holds a Ph.D. degree in financial economics from the University of New Orleans and served as a research fellow for Samsung Economic Research Institute.

E-mail: jsyu@dankook.ac.kr

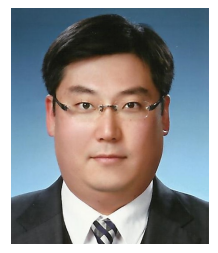

Zong Woo Geem is an associate professor in College of Information Technology, Gachon University. He received his B.E. from ChungAng University, M.Sc. from Johns Hopkins University, and $\mathrm{Ph} . \mathrm{D}$. from Korea University. He has researched at Virginia Tech, University of Maryland College Park, and Johns Hopkins University. He invented a music-inspired algorithm, Harmony Search, which has been applied to various optimization problems. His research interest includes phenomenon-mimicking algorithm and its applications to energy, environment and water fields.

E-Mail: geem@gachon.ac.kr 